\title{
PHYTOL-CONTAINING SEAWEED EXTRACTS AS CONTROL FOR Ganoderma boninense
}

\section{SYAMIMI DIYANA ABDUL AZIZ*; NUR FAZIRAH JAFARAH* and ZETTY NORHANA BALIA YUSOF**}

\begin{abstract}
Basal stem rot (BSR) is a disease in oil palm caused by a fungal pathogen, Ganoderma boninense. Utilisation of seaweeds as a control agent has not been explored. This study investigated the anti-fungal potential of Malaysian seaweed extracts against G. boninense and identification of the compounds. Seaweeds ${ }_{f f}$ Sargassum oligocystum, Caulerpa racemosa, Caulerpa racemosa var. lamouroxii and ${ }_{c f}$ Halimeda macrophysa were collected and subjected to crude extraction with various solvents. Methanolic extracts of all species displayed the highest yield with an average of $15.25 \%$ compared to dry weight. Anti-fungal assays were carried out against G. boninense using the poisoned food technique and three highest inhibitions were exhibited by C. racemosa var. lamouroxii dichloromethane extract $(46.82 \%),{ }_{c f} \mathrm{H}$. macrophysa dichloromethane extract (33.49\%) and C. racemosa methanol extract (28.06\%). Dominant compounds detected via gas chromatography-mass chromatography (GC-MS) in extracts with anti fungal potential includes phytol. Anti-fungal assay using standard phytol showed growth inhibition of $\mathrm{G}$. boninense of up to $21 \%$ inhibition. Caulerpa racemosa var. lamouroxii, ${ }_{c f}$ H. macrophysa, C. racemosa and ${ }_{c f}$ S. oligocystum dichloromethane extracts contain 474, 117, 106 and $19 \mathrm{mg} \mathrm{litre}^{-1}$ of phytol respectively. These findings suggested that Malaysian seaweeds are a good source of anti-fungal compounds for utilisation in controlling the BSR disease of oil palm in Malaysia.
\end{abstract}

Keywords: anti-fungal activity, basal stem rot disease, Ganoderma boninense, phytol, seaweeds.

Date received: 23 September 2018; Sent for revision: 12 October 2018; Received in final form: 28 February 2019; Accepted: 30 April 2019.

\section{INTRODUCTION}

Oil palm is a major source of edible vegetable oil and biodiesel fuel in Malaysia (Hushiarian et al., 2015). However, it is confronted with a devastating disease caused by a fungus, Ganoderma boninense. This fungus acts as the main factor that causes basal stem rot (BSR) disease which affects the production of palm oil and finally results in death (Khairudin, 1990; Rao, 1990; Hushiarian et al., 2015). Many

* Department of Biochemistry, Faculty of Biotechnology and Biomolecular Sciences, Universiti Putra Malaysia, 43400 UPM Serdang, Selangor, Malaysia.

** Laboratory of Marine Biotechnology, Institute of Bioscience, Universiti Putra Malaysia, 43400 UPM Serdang,

Selangor, Malaysia.

E-mail: zettynorhana@upm.edu.my approaches to prevent this disease have been done but the most common method is by applying nonenvironmental-friendly fungicide which is also costly at the same time (Idris et al., 2002). Therefore, a more environmental-friendly and sustainable remedy to this disease would be worth exploring. Seaweeds or also known as macrolagae are marine plants which have shown to have some fungicidal potential (Demirel et al., 2009). A number of studies have proposed the potential of seaweeds in inhibiting fungal species (Khanzada et al., 2007; Aruna et al., 2010; Manivannan et al., 2011; Stein et al., 2011; Peres et al., 2012; Rajasulochana et al., 2013; Am et al., 2015; Ambika and Sujatha, 2015). For example, a study by Rajasulochana et al. (2012) showed Kappaphycus alvarezii expressed maximum activity against Pseudomonas fluorescence, Aspergillus 
fumigatus and Staphylococcus aureus but lower inhibition on Vibrio cholera and Proteus mirabilis. In another study, five brown seaweed extracts namely Sargassum vulgare, Cystoseira barbata, Dictyopteris membranacea, Dictyota dichotoma and Colpomenia sinuosa, displayed high anti-fungal activities against eight fungal species. Some algal extracts even exhibited anti-fungal activity that is relative to commercial anti-fungal medicine (Am et al., 2015). Seaweeds are abundant in Malaysia and most of their potential and advantages are under-explored. This study aimed to discover the possession of anti-fungal characteristics and identification of the bioactive compounds in the abundantly available Malaysian seaweeds which could be the answer to the quest of an environmental-friendly approach to control the BSR disease in oil palm.

\section{MATERIALS AND METHODS}

\section{Collection of Seaweeds}

Seaweeds were collected from Teluk Kemang, Port Dickson, Negeri Sembilan, Malaysia $\left(2^{\circ} 26^{\prime}\right.$ N latitude; $101^{\circ} 51^{\prime}$ E longitude). The collected seaweeds were brown seaweed ( $\mathrm{cf}$. oligocystum) and green seaweeds (C. racemosa var. lamouroxii, C. racemosa and $H$. macrophysa). The handling procedures of the collected seaweeds were according to the method by Abirami and Kowsalya (2012) but the samples were freeze-dried using a freeze-dryer for seven days. The seaweeds were then ground into fine powder using a mechanical blender and weighed.

\section{Preparation of Crude Extracts}

Ten grams of the seaweed powder was extracted with $250 \mathrm{ml}$ solvent (dichloromethane, methanol and chloroform) via Soxhlet extraction (Abirami, 2012).

\section{Anti-fungal Assay}

All of the seaweed extracts were tested using the poisoned food technique (Schmitz, 1930; Bussaman et al., 2012) with the concentration of 0.25 , 0.5 and $1.0 \mathrm{mg} \mathrm{ml}^{-1}$ of seaweed extracts. Triadimefon was chosen as positive control due to its ability in inhibiting fungal growth (Jayaratne et al., 2001).

Inhibition percentage of $G$. boninense was measured using the following equation:

$$
\% \text { Inhibition }=\frac{(\mathrm{ADC}-\mathrm{ADT})}{(\mathrm{ADC})} \times 100
$$

ADC - average diameter of fungal culture on negative control plate.

ADT - average diameter of fungal culture on plates treated with seaweed extracts.

\section{Identification of Potential Anti-fungal Compounds Using GC-MS}

Preparation of methanol extract for solid phase extraction (SPE) was done using the method by Abdullah et al. (2014) while the dichloromethane and chloroform extracts were subjected to syringe filtration to remove impurities. Compounds from both extracts were identified using Thermo Scientific TSQ Quantum XLS gas chromatography (GC) (country of origin: USA). The GC capillary column with HP-5MS stationary phase $(30 \mathrm{~m} \mathrm{x}$ $0.25 \mathrm{~mm} \times 0.25 \mu \mathrm{m})$ and composed of (5\%-phenyl)methylpolysiloxane was used. The final concentration of crude extracts was prepared to 0.1 $\mathrm{g} \mathrm{ml}^{-1}$ by dissolving $0.1 \mathrm{~g}$ of the crude extract in 1 $\mathrm{ml}$ of solvent used for extraction and mixed well. The ionisation energy used was $70 \mathrm{eV}$ and helium gas $(99.999 \%)$ was used as carrier gas at constant flow rate of $1.0 \mathrm{ml} \mathrm{min}^{-1}$ and an injection volume of $1 \mu \mathrm{l}$ (split ratio 10:1). The injection temperature was set at $250^{\circ} \mathrm{C}$ and ion source temperature at $280^{\circ} \mathrm{C}$, the oven temperature was programmed from $110^{\circ} \mathrm{C}$ (isothermal for $2 \mathrm{~min}$ ) with an increase of $10^{\circ} \mathrm{C}$ $\mathrm{min}^{-1}$, to $200^{\circ} \mathrm{C}$, then $5^{\circ} \mathrm{C} \mathrm{min}-1$ to $280^{\circ} \mathrm{C}$ (isothermal for $9 \mathrm{~min}$ ). Mass spectra were taken at $70 \mathrm{eV}$ (a scan interval of $0.5 \mathrm{~s}$ and fragments from 40 to $550 \mathrm{Da}$ ). The total GC running time was $36 \mathrm{~min}$. The relative percentage of each component was calculated by comparing its average peak area to the total area. The software used to handle mass spectra and chromatograms was Xcalibur (Upgade and Bhaskar, 2013).

Anti-fungal Activity of Phytol against G. boninense

The anti-fungal activity of phytol against G. boninense was determined by poisoned food technique (Schmitz, 1930). The phytol standard (Chemfaces) was prepared using dimethylsulphoxide (DMSO, 1.0\% v/v) as the initial solvent carrier followed by dilution with Potato Dextrate Agar (PDA) (at about $50^{\circ} \mathrm{C}$ ) containing final concentration of $100 \mu \mathrm{g} \mathrm{ml}^{-1}$ antibiotics ampicillin and penicillin to give the desired concentrations of $0.25,0.5$ and $1.0 \mathrm{mg} \mathrm{ml}^{-1}$. The agar was left to solidify, and a $6 \mathrm{~mm}$ mycelial disk was cut from the periphery of one-week old cultures, placed in the centre of each PDA plate, and then incubated at $27^{\circ} \mathrm{C}$ for seven days (Schmitz, 1930; Bussaman et al., 2012).

\section{Quantification of Phytol in Seaweed Extracts}

Calibration curve. Calibration curve (peak area versus concentration) was plotted by using the calibration point of phytol standard solution. The compound phytol is quantified by interpolation of the sum of two selected ions peak areas into the 
linear plot. In the single-ion monitoring (SIM) mode for quantification, a molecular peak ion for phytol was selected as a quantitative ion $(\mathrm{m} / \mathrm{z}$ 297). The start time for ion monitoring was programmed from 4.0 to $36.0 \mathrm{~min}$. A pullup delay of $100 \mathrm{~ms}$ and an emission current of $70 \mu \mathrm{A}$ was applied for the ion monitored.

Evaluation of repeatability and reproducibility. The repeatability of the chromatographic analysis was determined in a day by 10 replicates of $1 \mu \mathrm{l}$ injections of a phytol standard solution at $250 \mathrm{ppm}$ level. The reproducibility for phytol was examined every other day $(n=3)$ by $1 \mu$ injection of the standard solution at 250 ppm levels.

\section{Data Analysis}

Each treatment was replicated three times and the results were expressed as mean \pm standard deviation. The median values were subjected to Kruskal-Wallis $\mathrm{H}$ tests (SPSS statistical package, version 22) was used to determine the significant differences $(p<0.05)$ between treatments.

\section{RESULTS AND DISCUSSION}

\section{Extraction Yield}

Figure 1 shows the extraction yield of the dichloromethane, methanol and chloroform extracts. Three of the different extraction solvents were used per the order of their increasing polarity as different compound gets extracted in different solvents. Considerable variations in extraction yield were observed among different seaweed species. From $10 \mathrm{~g}$ of seaweed powder, methanol extraction relatively produced the highest yield for all seaweed samples. The yield of the extract was obtained by the following equation (Hasmida et al., 2014):

$$
\begin{aligned}
& \text { Yield }(\%)=\frac{W E}{W P} \times 100 \\
& \text { WE - dry weight of extract. } \\
& \text { WP - dry weight of plant powder. }
\end{aligned}
$$

The extraction yield of dichloromethane extracts ranged from $1.19 \%$ to $7.85 \%$, methanol extracts ranged from $7.11 \%$ to $21.20 \%$, and chloroform extracts ranged from $1.98 \%$ to $7.11 \%$. Extraction yield of seaweed extracts was obtained by measuring the weight of crude extracts from Soxhlet extraction. The selection of extraction solvent and method are crucial for extraction of marine compound of interest (Misra et al., 2015). Different solvents have the capacity to solubilise different compounds based on the polarity of the solvent (Hediat and Najat, 2010). In this study, methanol displayed the best extraction capability of most seaweed species compared to the other solvents. This might be due to the polarity of methanol which makes it able to extract not only the polar compounds but also some non-polar compounds that are miscible to methanol such as phenolics, fatty acids, sterols, alkaloids, hydrocarbons and more (Abdel-Aal et al., 2015). Chloroform, on the other hand, is a nonpolar solvent which can only solubilise non-polar compounds such as phenolics, diterpene alcohols, fatty acids and other non-polar compounds (Abdel-

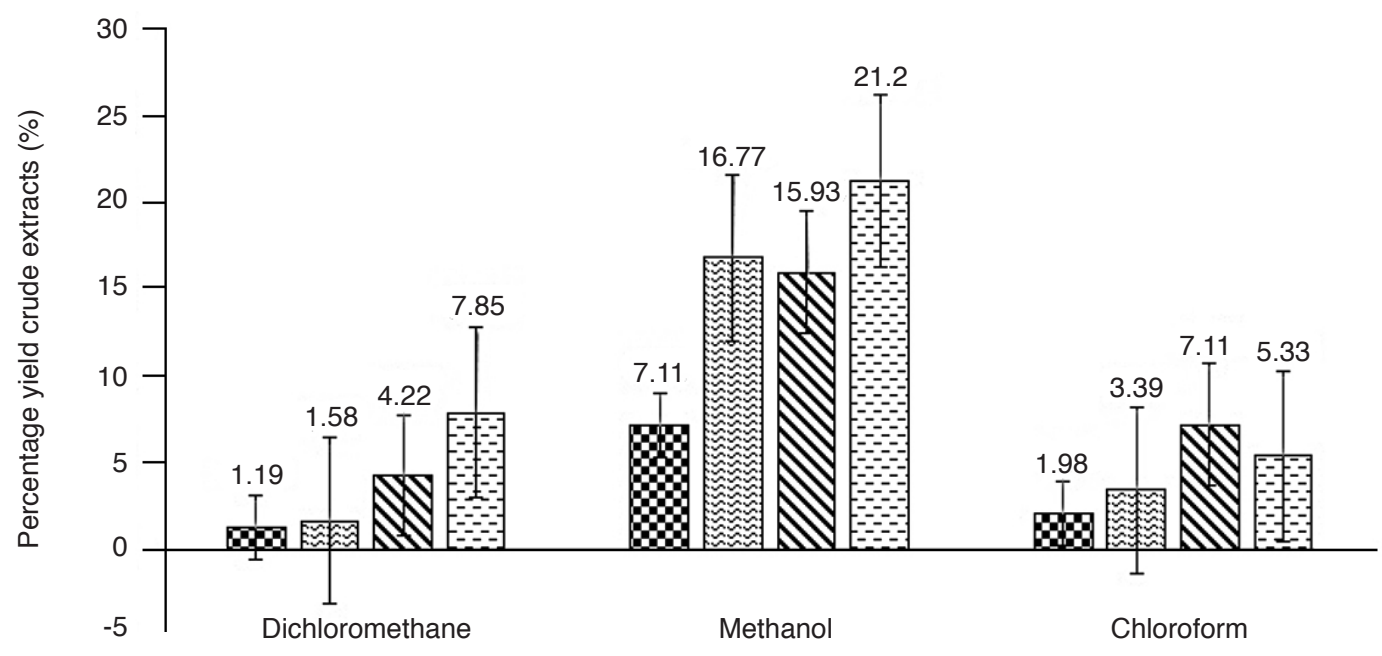

Extraction solvents

Figure 1. The percentage of extraction yield of the different solvent extracts. Each measure represents average from three replicates per treatment performed in triplicate and the bars represent standard error. Checker board pattern represents $\mathrm{cf}$. oligocystum; wave pattern represents C. racemosa; diagonal stripes pattern represents $\mathrm{C}$. racemosa var. lamouroxii; horizontal stripes pattern represents ${ }_{\mathrm{cf}} \mathrm{H}$. macrophysa. 
Aal et al., 2015). Dichloromethane, however, is a polar solvent which is able to extract only polar compounds.

\section{In vitro Growth Reduction Effect of Seaweed Crude Extracts on G. boninense}

The anti-fungal activity of seaweed crude extracts from all three solvents against $G$. boninense were studied in vitro via poisoned food technique. Ganoderma boninense took seven days to completely grow in $9 \mathrm{~cm}$ petri plate. This plate acted as control. Based on the observation made on plates containing seaweed crude extracts, some showed significant reduction of $G$. boninense growth at certain concentrations. As can be seen from the graph in Figures 2 to 5, S. oligocystum methanol and dichloromethane extracts exhibited optimum antifungal activity at the concentration of $0.50 \mathrm{mg} \mathrm{ml}^{-1}$ with $33.02 \%$ and $42.02 \%$ inhibition but decrease extremely as the concentration increased. For $S$. oligocystum chloroform extract, the anti-fungal activity increased at increasing concentration, and the highest inhibition percentage was $37.83 \%$. Similarly, the anti-fungal activity of $C$. racemosa var. lamouroxii methanol and chloroform extracts increased at increasing concentration with inhibition percentage of $30.7 \%$ and $33.18 \%$ respectively. For C. racemosa var. lamouroxii dichloromethane extract, the highest activity exhibited at the lowest concentration of $0.25 \mathrm{mg} \mathrm{ml}^{-1}$ with growth reduction of up to $46.82 \%$ but reduced with increasing concentration of the extract. Caulerpa racemosa methanol extract slightly reduced when the concentration increased. While $C$. racemosa dichloromethane and chloroform extracts demonstrated optimum anti-fungal activity at concentration of $0.50 \mathrm{mg} \mathrm{ml}^{-1}$ with inhibition $50.08 \%$ and $39.33 \%$, respectively. Finally, the anti-fungal activity of $H$. macrophysa for all solvents showed fluctuated inhibition percentage whereby the inhibition percentage was low at concentration of $0.50 \mathrm{mg} \mathrm{ml}^{-1}$ but increased again at concentration of $1.0 \mathrm{mg} \mathrm{ml}^{-1}$.

Marine algae have been reported for various important biological activities such as antimicrobial (Demirel et al., 2009), anti-viral (Newman et al., 2003), anti-inflammation (Ranganayaki et al., 2014), anti-coagulant (Chanda et al., 2010), antifouling (Maréchal et al., 2004) and anti-fungal activity (Ambika and Sujatha, 2015; Andreea et al., 2000; Pandian et al., 2011; Saidani et al., 2012). In this study, almost all the algal extracts tested showed anti-fungal activity against $G$. boninense proving that crude extracts of marine algae using various solvents may contain bioactive compounds with potential use. Caulerpa racemosa var. lamouroxii and C. racemosa extracts proved to show good anti-fungal potential while ${ }_{\mathrm{cf}} \mathrm{S}$. oligocystum and ${ }_{\mathrm{cf}} \mathrm{H}$. macrophysa exhibited low anti-fungal activity against $G$. boninense. A Kruskal-Wallis $\mathrm{H}$ test was conducted to explore the effect of solvents and species of extracts towards growth reduction percentage of $G$. boninense. There is statistically significant difference, $\mathrm{r}=21.48, p=.00 \mathrm{in}$ growth reduction percentage between the different solvent with a mean rank growth reduction percentage of 38.63 for solvent dichloromethane, 72.61 for solvent methanol and 52.26 for solvent chloroform. The effect of different seaweed species tested towards growth reduction percentage showed no statistically significant difference, $r=4.1, p=.25$ with a mean rank growth reduction percentage of 58.61 for species ${ }_{\text {cf }} S$. oligocystum, 50.11 for species

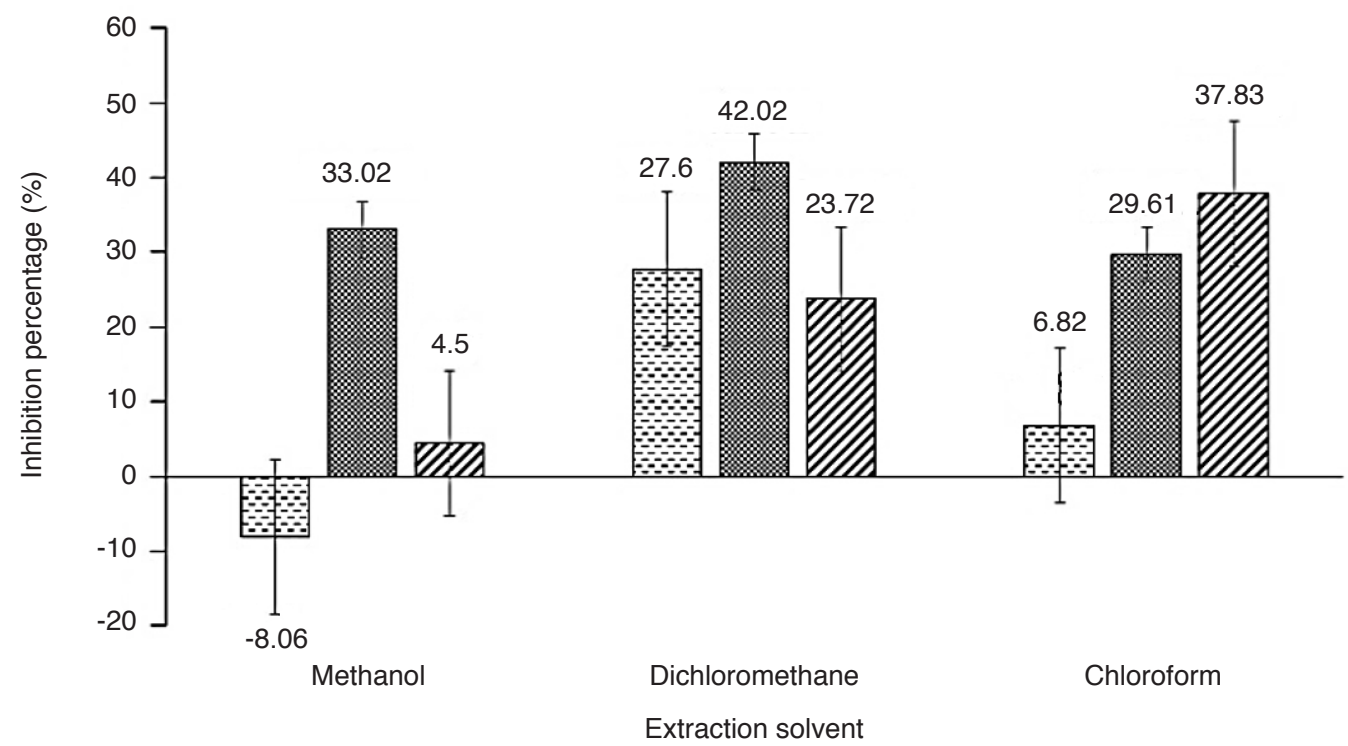

Figure 2. Average G. boninense growth reduction of s.oligocystum extract concentrations. Each measure represents average from three replicates per treatment performed in triplicate and the bars represent standard error. Horizontal stripes pattern represents $0.25 \mathrm{mg}_{\mathrm{g}} \mathrm{l}^{-1}$; small checker board pattern represents $0.50 \mathrm{mg} \mathrm{ml}^{-1}$; diagonal stripes pattern represents $1.0 \mathrm{mg} \mathrm{ml}^{-1}$. 


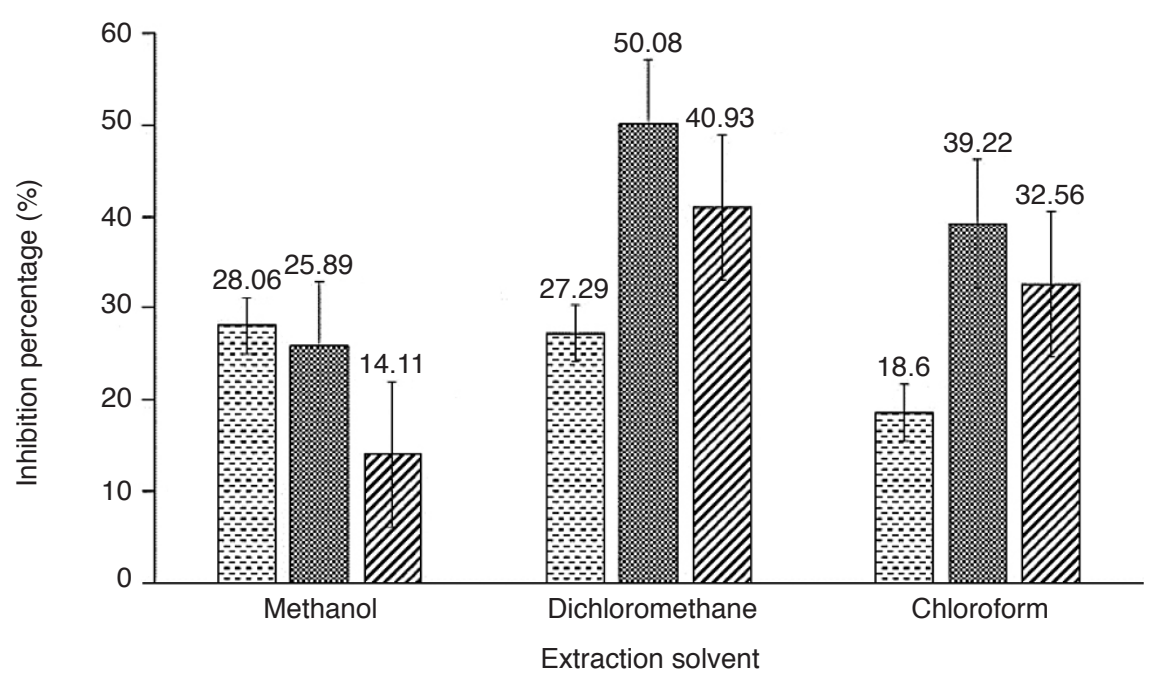

Figure 3. Average G. boninense growth reduction of C. racemosa extract concentrations. Each measure represents average from three replicates per treatment performed in triplicate and the bars represent standard error. Horizontal stripes pattern represents $0.25 \mathrm{mg} \mathrm{ml}^{-1}$; small checker board pattern represents $0.50 \mathrm{mg} \mathrm{ml}^{-1}$; diagonal stripes pattern represents $1.0 \mathrm{mg} \mathrm{ml}^{-1}$.

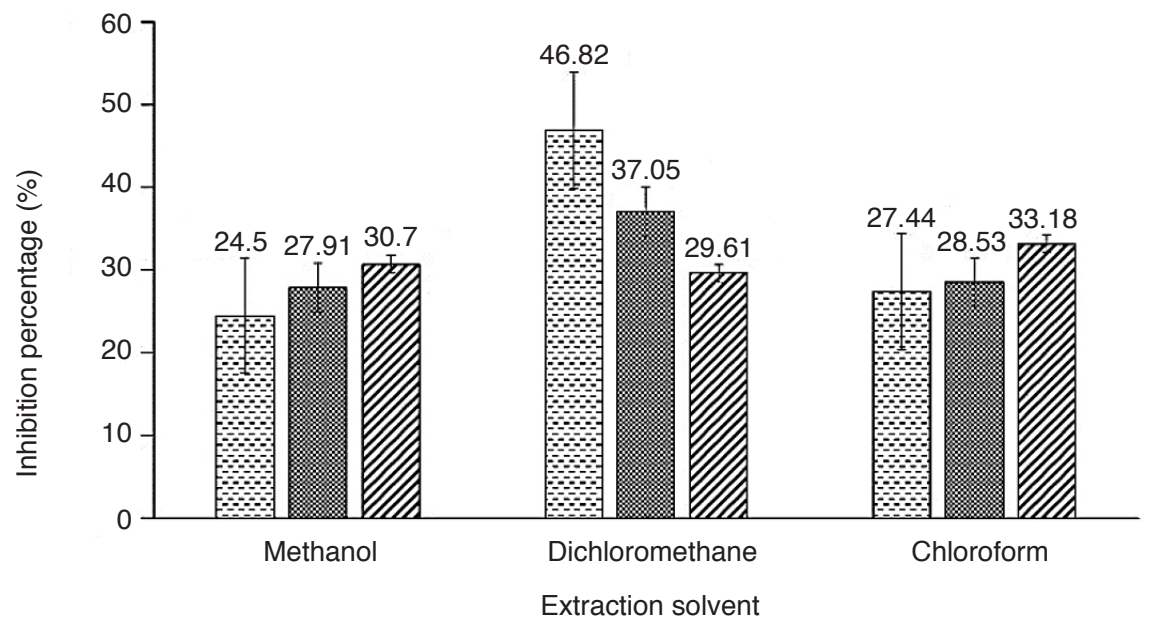

Figure 4. Average G. boninense growth reduction of C. racemosa var. lamouroxii extract concentrations. Each measure represents average from three replicates per treatment performed in triplicate and the bars represent standard error. Horizontal stripes pattern represents $0.25 \mathrm{mg} \mathrm{ml}^{-1}$; small checker board pattern represents $0.50 \mathrm{mg} \mathrm{ml}^{-1}$; diagonal stripes pattern represents $1.0 \mathrm{mg} \mathrm{ml}^{-1}$.

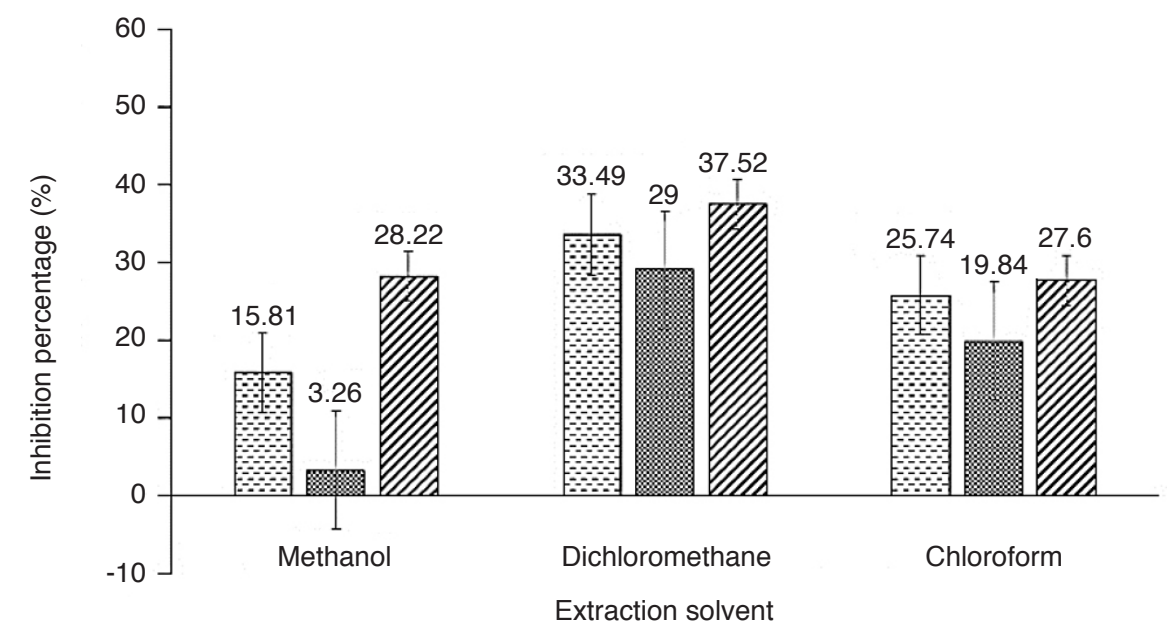

Figure 5. Average G. boninense growth reduction of ${ }_{c f} \mathrm{H}$. macrophysa extract concentrations. Each measure represents average from three replicates per treatment performed in triplicate and the bars represent standard error. Horizontal stripes pattern represents $0.25 \mathrm{mg} \mathrm{ml}^{-1}$; small checker board pattern represents $0.50 \mathrm{mg} \mathrm{ml}^{-1}$; diagonal stripes pattern represents $1.0 \mathrm{mg} \mathrm{ml}^{-1}$. 
C. racemosa, 47.13 for species C. racemosa var. lamouroxii and 62.15 for species ${ }_{\mathrm{cf}} \mathrm{H}$. macrophysa.

However, there are many factors that should be taken into account namely their habitat, season, and also growth stage (Karthikaidevi et al., 2009).

\section{GC-MS Analysis of Anti-fungal Compounds in Seaweed Extracts}

Seaweed extracts with significant anti-fungal activities of above $30 \%$ growth reduction at concentration of $0.25 \mathrm{mg} \mathrm{ml}^{-1}$ were further analysed using GC-MS. Compounds from the extracts were identified by comparing the output of the analysis to the National Institute of Standard and Technology (NIST) database. A total of five major compounds were identified in ${ }_{\mathrm{cf}} \mathrm{S}$. oligocystum dichloromethane extract as shown in Table 1.

For C. racemosa var. lamouroxii, there were six major compounds identified in its methanol extract, and five major compounds in its dichloromethane and chloroform extracts as shown in Table 2.
While in C. racemosa extract, five major compounds were identified in both methanol and dichloromethane extracts as shown in Table 3.

Finally, there were six major compounds with high probability identified in $H$. macrophysa dichloromethane and chloroform extracts as shown in Table 4.

Based on the results obtained all extracts mainly consist of compound from the classes of phenolic compounds, vitamins, diterpene alcohol, fatty acids and sterols being identified as anti-microbials. Based on this finding, the bioactive compounds identified are expected to cause the inhibitory effect of seaweed extracts towards the growth of G. boninense in vitro. This includes the presence of phytol (Shobier et al., 2016), 1-(+)-ascorbic acid 2,6-dihexadecanoate (Karthikeyan et al., 2014), linolenic acid, linoleic acid (Raynor et al., 2004) and ethyl iso-allocholate (Tay and Chong, 2016) which are correlated with strong biological activity. Phytol was one of the compounds identified in most potential extracts and was tested alone with two concentrations, 0.25 and $0.50 \mathrm{mg} \mathrm{ml}^{-1}$

TABLE 1. CHEMICAL CONSTITUENTS OF ${ }_{\mathrm{cf}}$ S. oligocystum EXTRACTS

\begin{tabular}{|c|c|c|c|c|c|}
\hline Extracts & RT (min) & Component name & Molecular formula & MW (m/z) & Quality \\
\hline \multirow[t]{3}{*}{ methane } & 12.70 & Hexadecanal, 2-methyl- & $\mathrm{C}_{17} \mathrm{H}_{34} \mathrm{O}$ & 254 & 13.09 \\
\hline & 15.23 & Z,Z,Z-1,4,6,9-Nonadecatetraene & $\mathrm{C}_{19} \mathrm{H}_{32}$ & 260 & 17.03 \\
\hline & 33.64 & $\begin{array}{l}\text { Cholesta-8,24-dien-3-ol,4-methyl-, } \\
\text { (3á,4à)- }\end{array}$ & $\mathrm{C}_{28} \mathrm{H}_{46} \mathrm{O}$ & 398 & 15.08 \\
\hline
\end{tabular}

Note: MW - molecular weight. RT - retention time.

TABLE 2. CHEMICAL CONSTITUENTS OF C. racemosa var. lamouroxii EXTRACTS

\begin{tabular}{|c|c|c|c|c|c|}
\hline Extracts & RT (min) & Component name & Molecular formula & $\mathrm{MW}(\mathrm{m} / \mathrm{z})$ & Quality \\
\hline & 16.29 & Phytol & $\mathrm{C}_{20} \mathrm{H}_{40} \mathrm{O}$ & 296 & 22.82 \\
\hline & 20.10 & Ergosta-5,22-dien-3-ol, acetate, (3á,22E)- & $\mathrm{C}_{30} \mathrm{H}_{48} \mathrm{O}_{2}$ & 440 & 28.81 \\
\hline & 21.01 & $\begin{array}{l}\text { 9-Bromo-10-[2-pyridylamino]- } \\
\text { deoxoartemisinin }\end{array}$ & $\mathrm{C}_{20} \mathrm{H}_{27} \mathrm{BrN}_{2} \mathrm{O}_{4}$ & 438 & 26.18 \\
\hline \multirow{3}{*}{$\begin{array}{l}\text { Dichloro- } \\
\text { methane }\end{array}$} & 11.71 & Tetradecanoic acid & $\mathrm{C}_{14} \mathrm{H}_{28} \mathrm{O}_{2}$ & 228 & 49.29 \\
\hline & 14.29 & 1-(+)-Ascorbic acid 2,6-dihexadecanoate & $\mathrm{C}_{38} \mathrm{H}_{68} \mathrm{O}_{8}$ & 652 & 61.59 \\
\hline & 16.30 & Phytol & $\mathrm{C}_{20} \mathrm{H}_{40} \mathrm{O}$ & 296 & 60.46 \\
\hline \multirow{4}{*}{ Chloroform } & 17.25 & Hexadecanamide & $\mathrm{C}_{16} \mathrm{H}_{33} \mathrm{NO}$ & 255 & 64.74 \\
\hline & 19.91 & $\begin{array}{l}\text { Androst-4-en-11-ol-3,17-dione, } \\
\text { 9-thiocyanato- }\end{array}$ & $\mathrm{C}_{20} \mathrm{H}_{25} \mathrm{NO}_{3} \mathrm{~S}$ & 359 & 33.04 \\
\hline & 20.36 & $\begin{array}{l}\text { 18,3-Epoxypregn-9(11)-en-20-one, } \\
\text { 3á-methoxy-(5 beta)- }\end{array}$ & $\mathrm{C}_{22} \mathrm{H}_{32} \mathrm{O}_{3}$ & 344 & 28.12 \\
\hline & 20.41 & $\begin{array}{l}\text { 4a,10a-Methanophenanthren-9á-ol, } \\
\text { 11-syn-bromo-1,2,3,4,4a,9,10,10a- } \\
\text { octahydro- }\end{array}$ & $\mathrm{C}_{15} \mathrm{H}_{17} \mathrm{BrO}$ & 292 & 43.72 \\
\hline
\end{tabular}

Note: MW - molecular weight. RT - retention time. 
TABLE 3. CHEMICAL CONSTITUENTS OF C. racemosa EXTRACTS

\begin{tabular}{|c|c|c|c|c|c|}
\hline Extracts & $\mathrm{RT}$ (min) & Component name & Molecular formula & $\operatorname{MW}(\mathrm{m} / \mathrm{z})$ & Quality \\
\hline \multirow{3}{*}{ Methanol } & 14.21 & 1-(+)-Ascorbic acid 2,6-dihexadecanoate & $\mathrm{C}_{38} \mathrm{H}_{68} \mathrm{O}_{8}$ & 652 & 55.48 \\
\hline & 16.74 & Linolenic acid & $\mathrm{C}_{18} \mathrm{H}_{30} \mathrm{O}_{2}$ & 278 & 34.20 \\
\hline & 21.03 & 9,12,15-Octadecatrienoic acid, 2,3-bis & & & \\
\hline \multirow{4}{*}{$\begin{array}{l}\text { Dichloro- } \\
\text { methane }\end{array}$} & 14.39 & n-Hexadecanoic acid & $\mathrm{C}_{16} \mathrm{H}_{2} \mathrm{O}_{2}$ & 256 & 54.67 \\
\hline & 16.84 & 10-Undecyn-1-ol & $\mathrm{C}_{11} \mathrm{H}_{20} \mathrm{O}$ & 168 & 14.57 \\
\hline & 25.83 & 8-Methyl-6-nonenamide & $\mathrm{C}_{10} \mathrm{H}_{19} \mathrm{NO}$ & 169 & 24.10 \\
\hline & 31.58 & á-Tocopherol, O-methyl- & $\mathrm{C}_{29} \mathrm{H}_{50} \mathrm{O}_{2}$ & 430 & 21.81 \\
\hline
\end{tabular}

Note: MW - molecular weight. RT - retention time.

TABLE 4. CHEMICAL CONSTITUENTS OF ${ }_{\mathrm{c}} H$. macrophysa EXTRACTS

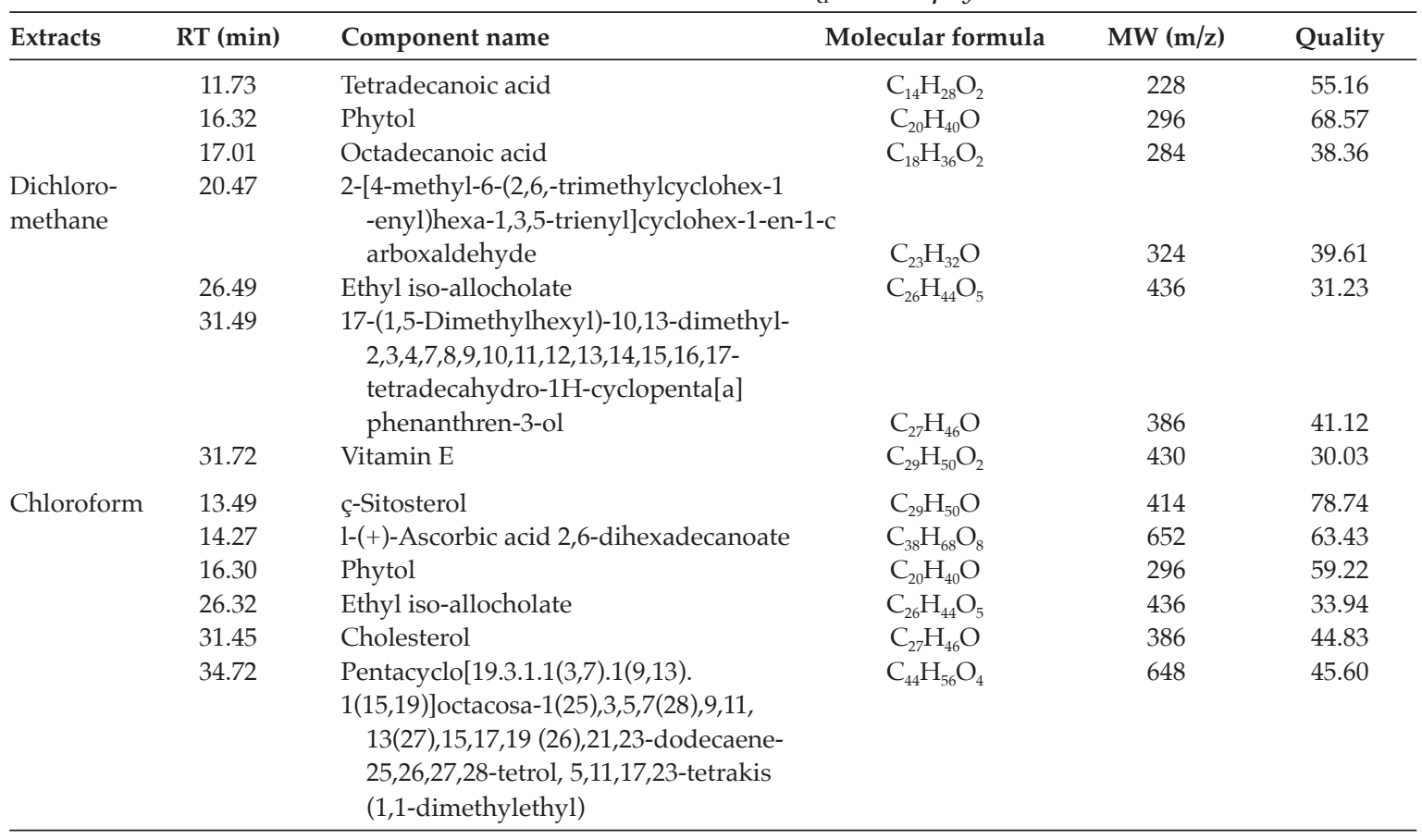

Note: MW - molecular weight. RT - retention time.

against $G$. boninense by using chemical standard via poison food technique showed positive results as shown in Figure 6.

The application of chemical standard phytol against $G$. boninense has shown significant antifungal activity from the two concentrations tested.

\section{Phytol Quantification of Seaweed-dichloro- methane Extracts via GC-MS}

Quantification of phytol content in the four seaweed-dichloromethane extracts that consistently exhibited high anti-fungal activities were carried out via GC-MS. Figure 7 shows that phytol was found to be abundant in C. racemosa var. lamouroxii extract followed by ${ }_{\mathrm{cf}} H$. macrophysa, C. racemosa and ${ }_{\text {cf }}$ S. oligocystum.

Phytol is known as product of chlorophyll metabolism in plants (Knaff, 1991) and was proven

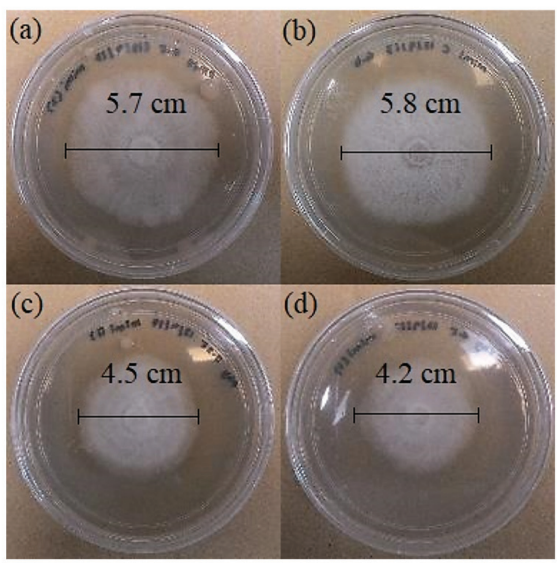

Figure 6. Anti-fungal assay of chemical standard phytol against G. boninense after seven days. (a) Negative control consists of agar associated with 1\% dimethyl-sulphoxide (DMSO). (b) Absolute control consist of agar without any solvent. (c) Agar associated with $0.25 \mathrm{mg}$ $\mathrm{ml}^{-1}$ concentration of phytol. (d) Agar associated with $0.50 \mathrm{mg} \mathrm{ml}^{-1}$ concentration of phytol. 


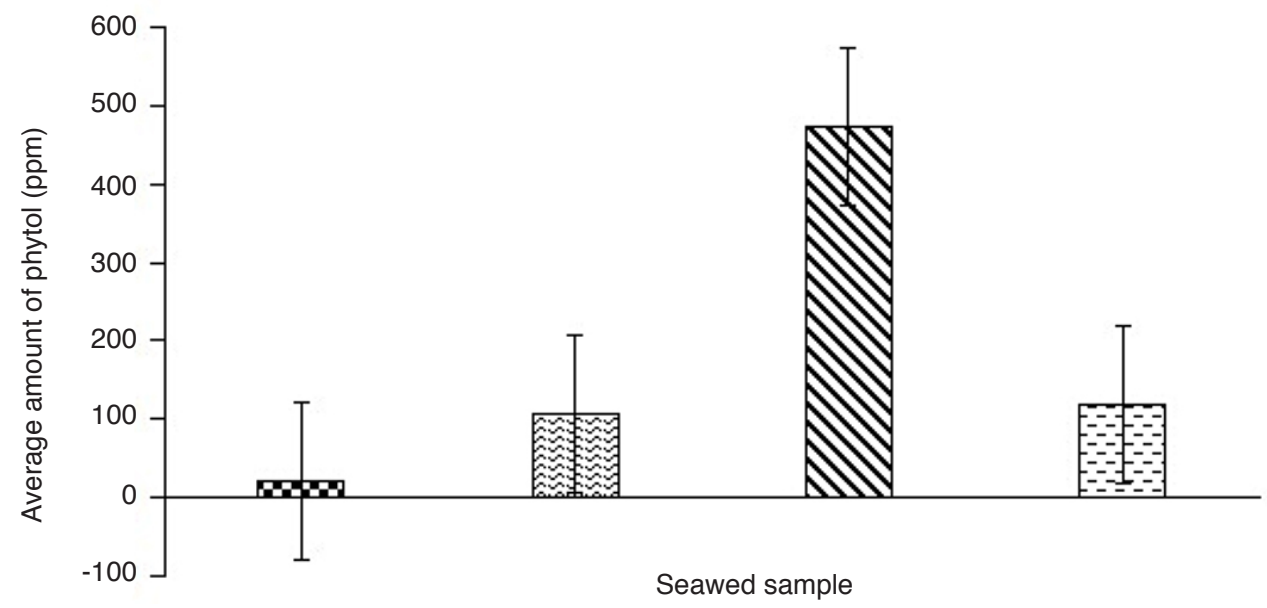

Figure 7. Calculated amount of phytol in seaweed-dichloromethane extracts. Each measure represents average from three replicates and the bars represent standard error. Checker board pattern represents ${ }_{c f}$ S. oligocystum; wave pattern represents $\mathrm{C}$. racemosa; diagonal stripes pattern represents C. racemosa var. lamouroxii; horizontal stripes pattern represents ${ }_{\text {cf }} \mathrm{H}$. macrophysa.

as an anti-microbial compound (Plaza et al., 2010; Ghaneian et al., 2015). Phytol possesses antibacterial activities against Staphylococcus aureus by damaging the cell membrane and causing leakages of potassium ions in the bacterial cells (Inoue et al., 2005). Phytol was found in high amount in C. racemosa var. lamouroxii extract which explained why the extract portrayed the highest inhibition percentage followed by ${ }_{\mathrm{cf}} \mathrm{H}$. macrophysa extract which also corresponded to its anti-fungal activity. Phytol was more concentrated in C. racemosa extract than in ${ }_{\text {cf }} \mathrm{S}$. oligocystum extract even though ${ }_{\mathrm{cf}} \mathrm{S}$. oligocystum extract exhibited higher inhibition percentage. It is suggested that there might be another anti-fungal compound in $\mathrm{S} S$. oligocystum extract that caused it to be more anti-fungal than $C$. racemosa extract. Further detailed quantification and compound identification of all the extracts that portrayed positive anti-fungal activity will definitely pave the way for the discovery of seaweeds as a source of useful anti-fungal compounds for various purposes.

\section{CONCLUSION}

In this study, it was found that the solvent methanol produced the highest crude seaweed extract yield. Caulerpa racemosa var. lamouroxii extract showed the best activity against $G$. boninense compared to other species tested. Seaweed-dichloromethane extracts consistently showed significant amount of inhibition against $G$. boninense at the lowest concentration tested which was $0.25 \mathrm{mg} \mathrm{ml}^{-1}$ suggesting that more anti-fungal compounds were extracted through this solvent. GC-MS analysis showed that phytol is one of the dominant compounds identified in the seaweed-dichloromethane extracts and was proven to contribute to the reduction of growth of $G$. boninense based on the assay using a standard. These findings will pave the way for further exploration of local seaweeds for bioactive compounds which could be useful for various purposes.

\section{ACKNOWLEDGEMENT}

The authors gratefully acknowledge Prof Phang Siew Moi from the Institute of Graduate Studies, Universiti Malaya for the authentication of seaweed species used in this research and Dr Nusaibah Syed Ali from the Faculty of Agriculture, Universiti Putra Malaysia for providing the fungal materials. This research was funded by Geran Putra IPS, Universiti Putra Malaysia (Project No. 9511100), Higher Institution Centre of Excellence (HICOE) Research Grant (Innovative Vaccines and Therapeutics against Fish Diseases) (Project No. 6369100), and SATREPS (JICA-JST): COSMOS-MOHE G4-B Research Grant (Microalgae for Sustainable Aquaculture Health: Microalgae Vaccine Delivery System) (Project No. 6300866).

\section{REFERENCES}

Abdel-Aal, E I; Haroon, A M and Mofeed, J (2015). Successive solvent extraction and GC-MS analysis for the evaluation of the phytochemical constituents of the filamentous green alga Spirogyra longata. Egypt. J. Aquat. Res., 41(3): 233-246. DOI: 10.1016/j. ejar.2015.06.001.

Abdullah, S; Gobilik, J and Phin Chong, K (2014). In vitro antimicrobial mode of action of Cynodon dactylon (L.) pers. solid phase extract (SPE) against selected pathogens. Dev. Sustain. Chem. Bioprocess Technol. (August 2015): 227-237. DOI: 10.13140/2.1.4052.4165. 
Abirami, R G (2012). Anticancer activity of methanolic and aqueous extract of Ulva fasciata in albino mice. Int. J. Pharm. Pharm. Sci., 4(2): 681-684.

Abirami, R G and Kowsalya, S (2012). Phytochemical screening, microbial load and antimicrobial activity of underexploited seaweeds. Int. Res. J. Microbiol., 3: 328-332.

Am, K; Im, D and Aa, F (2015). Antifungal potential in crude extracts of five selected brown seaweeds collected from the Western Libya coast. Microbiol. Mod. Tech., 1(1): 1-8.

Ambika, S and Sujatha, K (2015). Antifungal activity of aqueous and ethanol extracts of seaweeds against sugarcane red rot pathogen (Colletotrichum falcatum). Sci. Res. Essays. Academic J., 10(6): 232-235. DOI: 10.5897/SRE2015.6198.

Andreea, C; Oana, A and Beatrice, I (2000). Antifungal activity of macroalgae extracts. UASVM Bucharest Series A, LIII. p. 442-447. DOI: 10.1016/j. sajb.2014.03.016.

Aruna, P; Mansuya, P; Sridhar, S; Kumar, J S and Babu, S (2010). Pharmacognostical and antifungal activity of selected seaweeds from Gulf of Mannar region. Recent Res. Sci. Technol., 2(1): 115-119.

Balasubramanian, T (2011). Antimicrobial potential of selected brown seaweeds from Vedalai coastal waters, Gulf of Mannar. Asian Pac. J. Trop. Biomed., 1(2): 114-20. DOI: 10.1016/S2221-1691(11)60007-5.

Bussaman, P; Namsena, P; Rattasena, P and Chandrapatya, A (2012). Effect of crude leaf extracts on Colletotrichum gloeosporioides (Penz.) Sacc. Psyche Vol. 2012: 6 pp. DOI: 10.1155/2012/309046.

Chanda, S; Dave, R; Kaneria, M and Nagani, K (2010). Seaweeds: A novel, untapped source of drugs from sea to combat infectious diseases. Curr. Res. Technol. Educ. Top. Appl. Microbiol. Microb. Technol. (MendezVilas, A ed.). p. 473-480.

Demirel, Z; Yilmaz-Koz, F F; Karabay-Yavvasoglu, U N; Ozdemir, G and Sukatar, A (2009). Antimicrobial and antioxidant activity of brown algae from the Aegean Sea. J. Serbian Chem. Soc., 74(6): 619-628.

Ghaneian, M T; Ehrampoush, M H; Jebali, A; Hekmatimoghaddam, S and Mahmoudi, M (2015). Antimicrobial activity, toxicity and stability of phytol as a novel surface disinfectant. Environ. Heal. Eng. Manag. J., 2(1): 13-16.

Harlapur, S I; Kulkarni, M S; Wali, M C and Srikantkulkarni, H (2007). Evaluation of plant extracts, bio-agents and fungicides against Exserohilum turcicum causing Turcicum leaf blight of maize. J. Agric. Sci., 20(3): 541-544.

Hasmida, M N; Nur Syukriah, A R; Liza, M S and Mohd Azizi, C Y (2014). Effect of different extraction techniques on total phenolic content and antioxidant activity of Quercus infectoria galls. Int. Food Res. J., 21(3): 1039-1043.

Hediat, M H S and Najat, M (2010). Antimicrobial activity and phytochemical analyses of Polygonum aviculare L. (Polygonaceae), naturally growing in Egypt. Saudi J. Biol. Sci. Elsevier, 17(1): 57-63. DOI: 10.1016/j.sjbs.2009.12.009.

Hushiarian, R; Yusof, N A and Dutse, S W (2015). Detection and control of Ganoderma boninense: Strategies and perspectives. SpringerPlus, 2(1): 555. DOI: 10.1186/2193-1801-2-555.

Idris, A S; Ismail, S D and Ariffin, D (2002). Control of Ganoderma-infected palm-development of pressure injection and field applications. MPOB Information Series No. 131: 4 pp.

Inoue, Y; Hada, T; Shiraishi, A; Hirose, K; Hamashima, H and Kobayashi, S (2005). Biphasic effects of geranylgeraniol, teprenone, and phytol on the growth of Staphylococcus aureus. Antimicrob. Agents Chemother., 49(5): 1770-1774. DOI: 10.1128/ AAC.49.5.1770-1774. 2005.

Jayaratne, R; Wettasinghe, P C; Siriwardene, D and Peiris, P (2001). Systemic fungicides as a drench application to control white root disease of rubber. J. Rubber Res. Inst. Sri Lanka, 84: 1-17.

Karthikaidevi, G; Manivannan, K; Thirumaran, G; Anantharaman, P and Balasubaramanian, T (2009). Antibacterial properties of selected green seaweeds from Vedalai coastal waters; Gulf of Mannar marine biosphere reserve. Glob. J. Pharmacol., 3(2): 107-112.

Karthikeyan, S C; Velmurugan, S; Donio, M B S; Michaelbabu, M and Citarasu, T (2014). Studies on the antimicrobial potential and structural characterization of fatty acids extracted from Sydney rock oyster Saccostrea glomerata. Ann. Clin. Microbiol. Antimicrob. BioMed Central, 13(1): 332. DOI: 10.1186/ s12941-014-0057-x.

Khairudin, H (1990). Basal Stem Rot of Oil Palm: Incidence, Etiology and Control. Master of Agriculture Science thesis, Universiti Pertanian Malaysia, Selangor, Malaysia.

Khanzada, A K; Shaikh, W; Kazi, T G; Kabir, S and Soofia, S (2007). Antifungal activity, elemental analysis and determination of total protein of 
seaweed, Solieria Robusta (Greville) Kylin from the coast of Karachi. Pakistan J. Bot., 39(3): 931-937.

Knaff, D B (1991). Regulatory phosphorylation of chloroplast antenna proteins. Trends Biochem. Sci., 16: 82-83. DOI: 10.1016/0968-0004(91)90037-V.

Maréchal, J P; Culioli, G; Hellio, C; Thomas-Guyon, $\mathrm{H}$; Callow, M E; Clare, A S and Ortalo-Magné, A (2004). Seasonal variation in antifouling activity of crude extracts of the brown alga Bifurcaria bifurcata (Cystoseiraceae) against cyprids of Balanus amphitrite and the marine bacteria Cobetia marina and Pseudoalteromonas haloplanktis. J. Exp. Mar. Bio. Ecol., 313(1): 47-62. DOI: 10.1016/j.jembe.2004.07.016.

Misra, N N; Rai, D K and Hossain, M (2015). Chapter 10: Analytical techniques for bioactives from seaweed. Seaweed Sustain. p. 271-287. DOI: 10.1016/ B978-0-12-418697-2.00010-6.

Newman, D; Cragg, G and Snader, K (2003). Natural products as sources of new drugs over the period 1981- 2002. J. Nat. Prod., 66 (7): 1022-1037.

Pandian, P; Selvamuthukumar, S and Manavalan, R (2011). Screening of antibacterial and antifungal activities of red marine algae Acanthaphora spicifera (Rhodophyceae). J. Biomed Sci. and Res., 3(3): 444-448.

Peres, J C F; Carvalho, L R D; Gonçalez, E; Berian, L O S and Felicio, J D (2012). Evaluation of antifungal activity of seaweed extracts. Ciência e Agrotecnologia, 36:294-299. DOI: 10.1590/S1413-70542012000300004.

Plaza, M; Santoyo, S; Jaime, L and Reina, G G B (2010). Screening for bioactive compounds from algae. J. Pharm. Biomed. Anal., 51(2): 450-455.

Rajasulochana, P; Krishnamoorthy, $\mathrm{P}$ and Dhamotharan, R (2013). An investigation on the antioxidants, antifungal and antibacterial of the Kappaphycus alvarezii. Res. J. Pharm. Biol. Chem. Sci., 4(1): 586-594.

Rajasulochana, P; Krishnamoorthy, P and Dharmotharan, R (2012). Potential application of Kappaphycus alvarezii in agricultural and pharmaceutical industry. J. Chem. Pharm. Res., 4(1): 33-37.
Ranganayaki, P; Susmitha, S and Vijayaraghavan, R (2014). Study on metabolic compounds of Kappaphycus alvarezii and its in-vitro analysis of antiinflammatory activity. Int. J. Curr. Res. Acad. Rev., 2(10): 157-166.

Rao, A K (1990). Basal stem rot 'Ganoderma' problem in oil palm smallholdings - The West Johor experience. Proc. of Ganoderma Workshop. PORIM, Bangi. p. 36-48.

Raynor, L; Mitchell, A and Walker, R (2004). Antifungal activities of four fatty acids against plant pathogenic fungi. Mycopathologia, 157(1): 87-90. DOI: $10.1023 /$ B.

Saidani, K; Bedjou, F; Benabdesselam, F and Touati, $\mathrm{N}$ (2012). Antifungal activity of methanolic extracts of four Algerian marine algae species. African J. Biotechnol., 11(39): 9496-9500. DOI: 10.5897/ AJB11.1537.

Schmitz, H (1930). Poisoned food technique. Ind. Eng. Chem. Ed., 2(4): 361-363.

Shobier, A H; Abdel Ghani, S A and Barakat, K M (2016). GC/MS spectroscopic approach and antifungal potential of bioactive extracts produced by marine macroalgae. Egypt. J. Aquat. Res., 42(3): 289-299. DOI: 10.1016/j.ejar.2016.07.003.

Stein, E M; Colepicolo, P; Afonso, F A K and Fujii, M T (2011). Screening for antifungal activities of extracts of the Brazilian seaweed genus Laurencia (Ceramiales, Rhodophyta). Brazilian J. Pharmacogn., 21(2): 290-295. DOI: 10.1590/S0102695X2011005000085.

Tay, Z H and Chong, K P (2016). The potential of papaya leaf extract in controlling Ganoderma boninense. IOP Conference Series: Earth and Environmental Science, 36: 1-7. DOI: 10.1088/17551315/36/1/012027.

Upgade, A and Bhaskar, A (2013). Characterization and medicinal importance of phytoconstituents of Carica Papaya from down south Indian region using gas chromatography and mass spectroscopy. Asian J. Pharm. Clin. Res., 6(Suppl.4): 101-106. 